\title{
EFFECT OF MWCNT ON PROTON CONDUCTING OF B2SA GRAFTED PVA HYBRID MEMBRANES FOR FUEL CELL APPLICATIONS
}

\author{
MALLUR BASAVARAJ ${ }^{1}$, S.V. GORBAL ${ }^{2}$, N. R. BANAPURMATH ${ }^{3} \&$ A.M. SAJJAN ${ }^{4}$ \\ ${ }^{l}$ Government Industrial Training Institute, Gadag, Karnataka, India \\ ${ }^{3,4}$ B.V.B. College of Engineering and Technology, KLE Technological University, Hubli, Karnataka, India \\ ${ }^{2}$ Jain college of Engineering and Research, Belagavi, Karnataka, India
}

\begin{abstract}
In spite of important applications in the expansion of proton exchange membranes (PEM) for fuel cell applications, there is still a big challenge to improve the mechanical strength and proton conductivity of the membranes to make the fuel cell technology feasible. The present work focuses on development of PEM membranes using B2SA grafted plain polyvinyl alcohol (PVA) reinforced with varied concentrations of nano sized Multiwalled Carbon Nanotubes (MWCNT) in the PVA holding matrix. Effects of MWCNTs reinforcements on the membrane properties were studied. The membranes were subjected to solubility and swelling tests and were characterized by using Fourier transform infrared (FTIR) spectroscopy, Thermo Gravimetric Analysis (TGA) for feasibility studies on their fuel cell applications. Microstructural characterization of the membranes was also done using FESEM Micrographs.

KEYWORDS: B2SA grafted plain polyvinyl alcohol,Multiwalled Carbon Nanotubes, Fourier transform infrared (FTIR) spectroscopy \& Thermo Gravimetric Analysis
\end{abstract}

Received: Sep 26, 2020; Accepted: Oct 16, 2020; Published: Oct 29, 2020; Paper Id.: IJIETDEC20201

\section{INTRODUCTION}

Energy is directly related to the most serious economic and social issues which influence the sustainable growth such as water supply, sanitation, transportation, food production, ecological superiority. The time of low-priced oil and gas is tentative and the magnitude of change needed is enormous while the gap is getting widened between the energy produced and consumed nationally and internationally. In the recent years, the idea of green energy has attracted significant concentration and its aim is to search technologies and methodologies that decrease or remove the generation of products or by-product that are dangerous to human healthiness or the environment or atmosphere. This initiative on green energy is fetching one of the major goals of proposing new processes and responses in the rising areas of nano science and nano technology. Fuel cells have received broad appreciation as a substitute renewable technique of energy generation. Fuel cell technology presents lot of advantages such as higher efficiency, simple structure, and pollution free environment. Fuel cells mechanically, have no moving parts, highly durable, long life span, and silent performance. Membrane is the one of the most important parts of the fuel cells and the membrane technology is widely considered and discovered mainly for fuel cell applications. Proton conductivity, temperature heat resistance, chemical and mechanical strength play a significant role in the selection of the appropriate membranes. Several researchers have proposed different type of membranes for fuel cell applications. Performance of membrane in the field of automotive industry has been reported in the literature (Hietala et al. 1995; Liang et al. 2003). Significance of radiation grafted membranes (Park et al. 2005; Chen et al. 2006; Maekawa et al. 2007; Phu et al. 2009), cross-linking of membranes (Bae et al. 2002; Won et al. 2003), plasma modified membranes 
(Basarir et al. 2006; Kerres et al. 1999; Schönberger et al. 2007) and blending of the existing PEM (Li et al. 2010; Kumar et al. 2010; Kreuer et al. 1996) were reported in the literature. Organic and inorganic hybrid composite membranes were found to be extremely helpful for integrated higher ionic property into the copolymer with acceptable mechanical stabilities and strength of the material used (Kim et al. 2003; Lee et al. 2012; Zhu et al. 2015; Li et al. 2015; Lu et al. 2016).Fuel cell membrane development based on the polymers with high proton conductivity and high Ion Exchange Capacity (IEC) values has been stressed. These IEC values indicate larger dimensional variation as well as adequate mechanical property with greater water absorption capacity and these membranes were unsuitable for PEMFCs based fuel cell applications (Hickner et al. 2004; Yang et al. 2017; Zhao et al. 2010). Problems and challenges in fuel cell technology with optimization of different parameters have been studied by several investigators (Munavalli et al. 2018; Feng et al. 2013; Kim et al. 2015; Wang et al. 2012). They have investigated various methods of optimizing polymer structures, production of composite membranes and cross linking of membranes as well. Different types of membranes including organic, inorganic and nano composite membranes were studied (Beydaghi et al. 2014). Proton conductivity could be improved by synthesized polyvinylalcohol and non-porous silica membranes containing the sulfonic acid groups with increased thermal stability and water retention. García-Cruz et al. 2016, worked on the mixed matrix membranes (MMM) using mixtures of chitosan (CS) and poly vinyl alcohol (PVA). The mixtures were used with a ratio of the 50:50 w/w doped with Graphene oxide (GO) and the membranes developed were characterized by scanning electron microscopy (SEM) analysis and thermo gravimetric analysis (TGA). Drawbacks associated with modifying the present Nafion membrane and non perfluorinated fuel cells were reported in the literature (Miyatake et al. 2012; Chen et al. 2015). Current effort was directed towards growth of the membranes and their composites, using polyimides. Experiments with developed fluorine-free alternative polymer membranes, and also composites using with Polybenzimidazole were reported in the literature (Ozdemir et al. 2017; Jeong et al. 2015). Nanocomposite films of polyvinyl alcohol (PVA) containing constant ratio of both single and multi-wall carbon nano tubes (MWCNT) were obtained by dispersion techniques and were investigated by different techniques (Alghunaim et al. 2016). Sulfonated poly(arylene ether sulfone) (SPAES) composite membranes were prepared using thermally-treated graphene oxide (GO) and poly (2,5-benzimidazole)-grafted graphene oxide (ABPBI-GO) as fillers for proton exchange membrane fuel cell (PEMFC) applications (Ko et al. 2015). Mixed matrix membranes (MMM) based on chitosan (CS) and poly (vinyl) alcohol (PVA) with a 50:50 w/w ratio doped with graphene oxide (GO) were prepared by solution casting and characterized by scanning electron microscopy (SEM), X-ray diffraction (XRD), thermogravimetric analysis (TGA), water uptake, alcohol permeability, ion exchange capacity (IEC) and $\mathrm{OH}^{\prime}$ conductivity measurements (Leticia at al. 2016). The blended membranes exhibit superior performance in direct methanol fuel cells (DMFC) compared to plain sulfonated poly(ether -ether ketone) (SPEEK) and Nafion 115 membranes due to enhanced proton conductivity and much suppressed methanol crossover while preserving good swelling stability (Li at a. 2010). Multiwall carbon nano tubes (MWCNTs) BP/polyvinyl alcohol (PVA) composites were fabricated by a sequence of vacuum filtration and polymer intercalation technique. The optimized conditions for achieving a uniform and stable dispersion of MWCNTs were found to be using ethanol as a dispersion medium, $54 \mu \mathrm{m}$ ultrasonic amplitude and 40 min sonication time. FTIR analysis and SEM spectra further confirmed the introduction of oxygenated groups (-COOH) on the surface of MWCNTs BP and the complete infiltration of PVA into the porous MWCNTs network (Min Juey et al. 2018). The graphene-MWNT hybrid nanostructure was synthesized by first modifying graphene surface using a cationic polyelectrolyte and MWNT surface with acid functionalization (Vinayan et al. 2012). 


\section{PROBLEM IDENTIFICATION}

In this present work an attempt has been made to increase efficiency and durability of PEMs by varying quantities of fillers of Multi Walled Carbon Nanotubes (MWCNTs) incorporated in the B2SA grafted with Polyvinyl Alcohol (PVA) as matrix and the developed membranes were optimized for the filler concentration based on the experimental investigation.

\section{Material Selection and Methodology}

This section highlights the material selected and the methodology adopted in the development of Proton Conducting Membranes for fuel cell application. PVA (Polyvinyl Alcohol) was used as the holding matrix while MWCNTs (Multiwalled Carbon Nano Tubes) were used as the filler material. In addition to this HCL (Hydrochloric Acid) and B2SA (Benzaldehyde-2-Sulphonic Acid Sodium Salt) were also used. PVA is a water-soluble synthetic polymer and has the idealized formula $\left[\mathrm{CH}_{2} \mathrm{CH}(\mathrm{OH})\right]_{\mathrm{n}}$. It has excellent film forming, emulsifying and adhesive properties. It is also resistant to oil, grease and solvents. It has high tensile strength and flexibility, as well as high oxygen and aroma barrier properties. However, these properties are dependent on humidity; in other words, with higher humidity more water is absorbed. The water, which acts as a plasticizer, will then reduce its tensile strength, but increase its elongation and tear strength.

\section{MWCNT (Multi-walled Carbon Nano Tubes):}

Multi-walled nano tubes (MWNTs) consist of multiple rolled layers (concentric tubes) of graphene. Multi Walled Carbon Nanotubes (MWCNTs) were procured from united nanotech. The MWCNTs have diameter ranging from 10-30 nm and its length varies from 1-2 microns which were sourced as strength fillers in this research work. These MWCNTs were manufactured through Chemical Vapour Deposition (CVD) technique. The purity of CNTs is 95\%. MWCNT sourced in this study as particulate filler as shown in Fig 1. Table 1 shows significant properties of MWCNTs used.

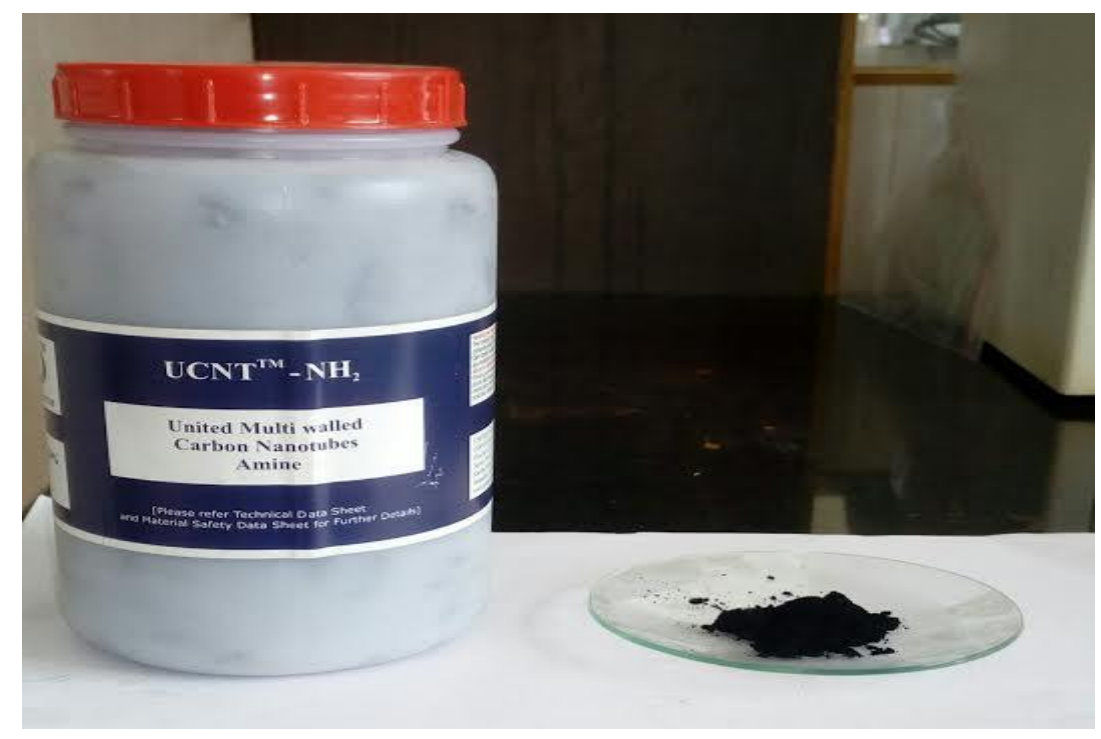

Figure 1: MWCNTs used as Filler Material in the Present Work

Table 1: Specification of MWCNTs

\begin{tabular}{|l|l|}
\hline \multicolumn{1}{|c|}{ Characteristic Property } & \multicolumn{1}{c|}{ Inferences } \\
\hline Manufacturing Process & Chemical Vapour Deposition (CVD) \\
\hline Diameter & $10-30 \mathrm{~nm}$ \\
\hline Length & $1-2$ microns \\
\hline Purity & $>95 \%$ (MWCNT) \\
\hline
\end{tabular}




\begin{tabular}{|l|l|}
\hline Amorphous carbon & $<3 \%$ \\
\hline Residue (Calcination in air) & $<2 \%$ \\
\hline Average interlayer distance & $0.34 \mathrm{~nm}$ \\
\hline Special surface area & $>350 \mathrm{~m}^{2} / \mathrm{g}$ \\
\hline Bulk density & $0.05-0.17 \mathrm{~g} / \mathrm{cm}^{3}$ \\
\hline Real density & $1-2 \mathrm{~g} / \mathrm{cm}^{3}$ \\
\hline Charging & $2180($ capacity: $\mathrm{mA} \mathrm{h} / \mathrm{g})$ \\
\hline Discharging & $534($ capacity: $\mathrm{mA} \mathrm{h} / \mathrm{g})$ \\
\hline Volume Resistivity & $0.1-0.15$ ohm.cm $(\mathrm{measured}$ at pressure in powder) \\
\hline
\end{tabular}

Hydrochloric acid (HCL), solution is a colourless watery liquid with a sharp, irritating odour. It consists of hydrogen chloride, a gas dissolved in water and sinks and mixes with water. HCL used in the preparation of membranes acts as a catalyst.

\section{Membrane Preparation}

Standard procedure as per ANSI/CSA was adopted in the preparation of the membranes using PVA and varied quantities of MWCNT in the holding matrix. For each concentration of the filler material six specimens were casted. Fabrication was done at room temperature by hand laying method or solution-cast method and membranes were cured at room temperature. The stock PVA and aqueous solution are prepared by dissolving $4 \mathrm{~g}$ of PVA in about $80 \mathrm{ml}$ of distilled water and then heating it to $60-70^{\circ} \mathrm{C}$ with continuous stirring using magnetic stirrer, until a transparent solution is obtained. The solution was casted on plain glass and left it for $24 \mathrm{hrs}$. for setting. After that casted membrane was taken out for further analysis. Figure 1 (a) and 1 (b) shows the casting Processand casted plain PVA respectively.

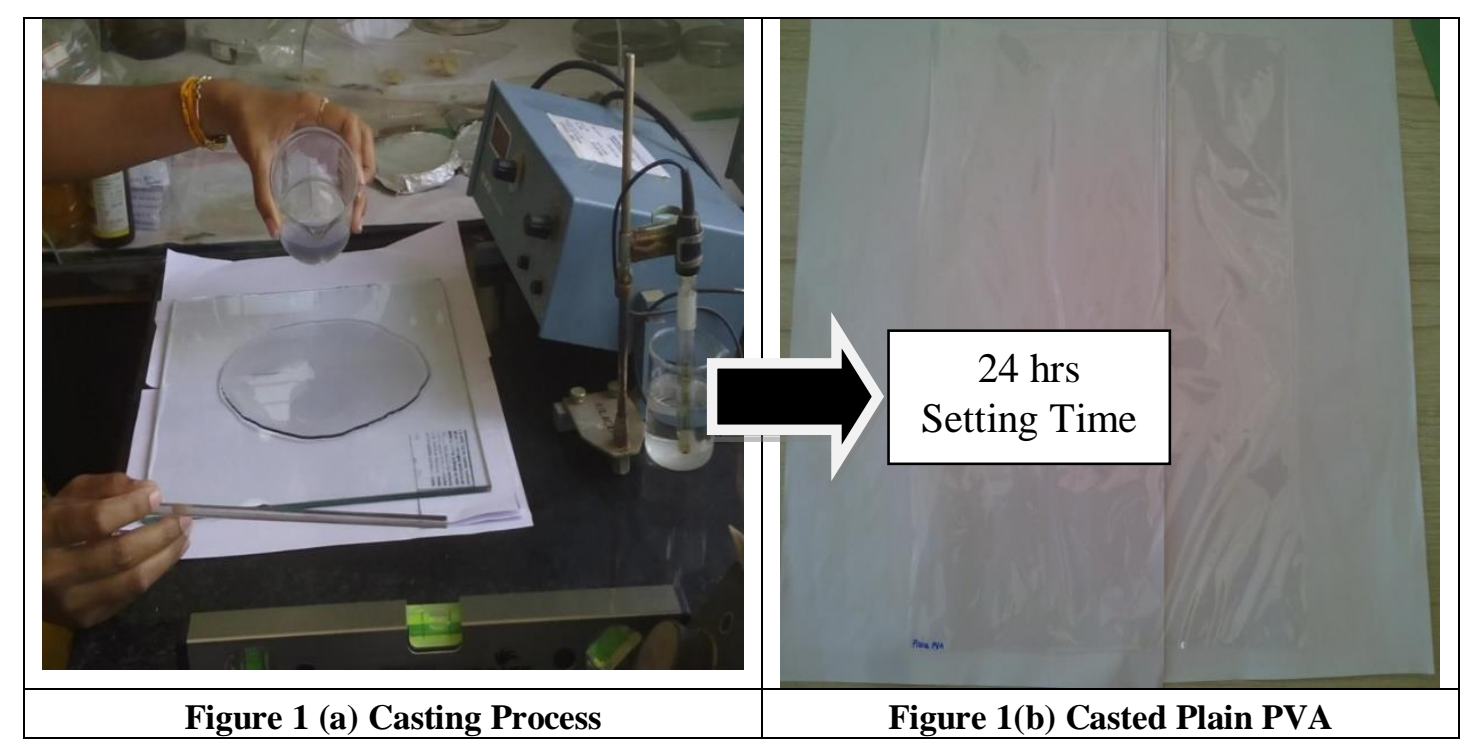

Similarly, other membranes were prepared with appropriate quantities of PVA polymer and varied amounts of MWCNT along with that $1 \mathrm{ml}$ of HCL which acts as a catalyst and 0.8g of B2SA (Benzeldehyde-2-Sulphonic Acid Sodium Salt). These mixtures were than stirred in a water bath stirrer for 18-20 hrs., and the mixture is sonicated using probe sonicator for uniform dispersion of MWCNT in to homogeneous viscous mixture.

Finally, all the four different solutions were casted on plain glass after checking its uniformity. Casted membranes were taken for further analysis. Table 2 shows the designation and detailed composition of membranes developed. 
Table 2: Designation and Detailed Composition of Membranes

\begin{tabular}{|l|l|}
\hline Designation & \multicolumn{1}{|c|}{ Composition } \\
\hline M0 & 4g of PVA \\
\hline M1 & $4 \mathrm{~g}$ of PVA $+0.01 \mathrm{~g}$ of MWCNT \\
\hline M2 & $4 \mathrm{~g}$ of PVA $+0.02 \mathrm{~g}$ of MWCNT \\
\hline M3 & $4 \mathrm{~g}$ of PVA $+0.03 \mathrm{~g}$ of MWCNT \\
\hline M4 & $4 \mathrm{~g}$ of PVA $+0.04 \mathrm{~g}$ of MWCNT \\
\hline
\end{tabular}

Figure 2 shows the weighed MWCNTs for the membrane preparation. Figure 3 shows the stirring of the mixture of PVA+MWCNTs combination.Figure 4shows casting of PVA+MWCNTs membranes.Figure 5 shows the casted membrane of PVA+MWCNTs for one selected composition.

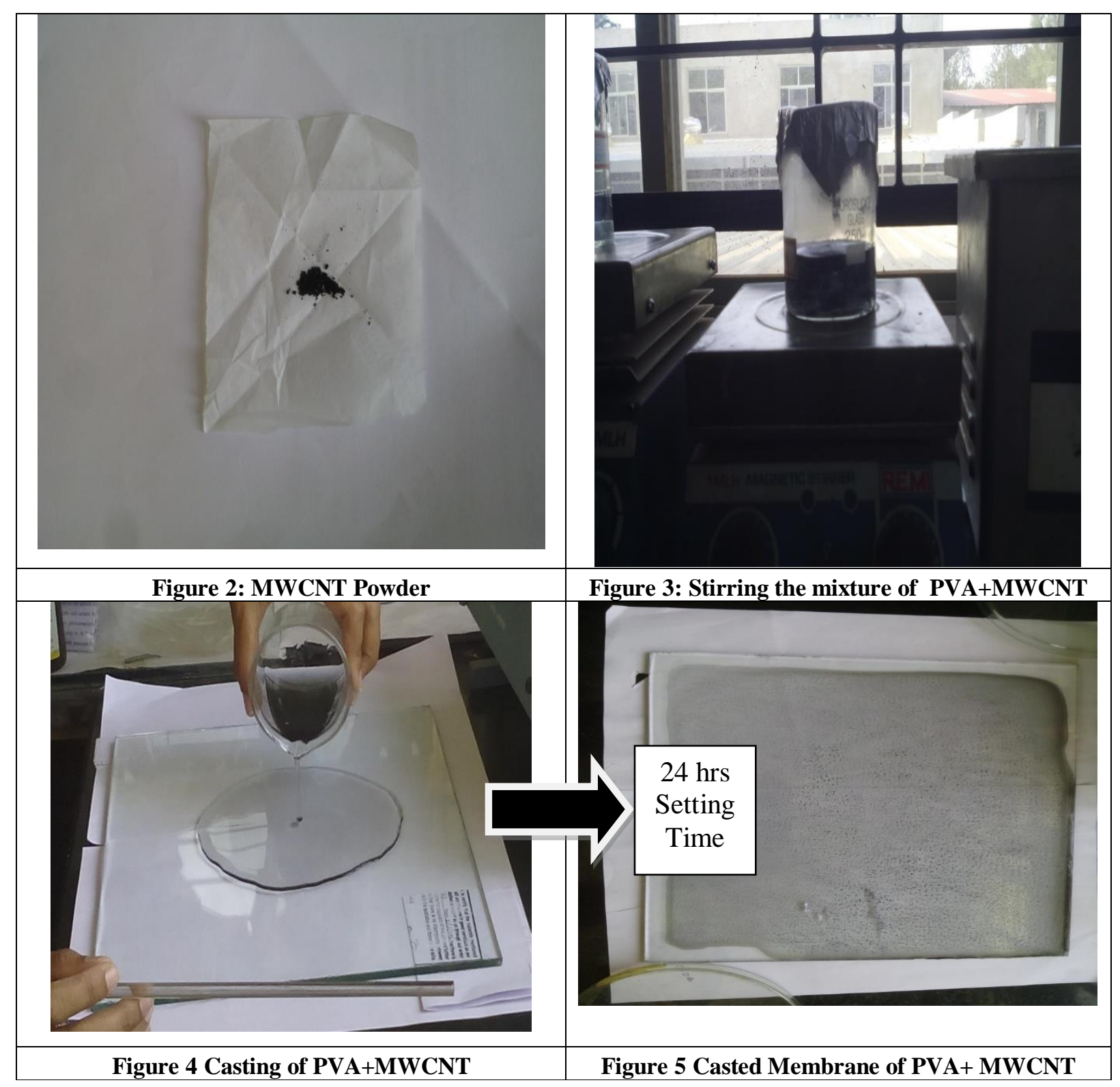




\section{RESULTS AND DISCUSSIONS}

To check the suitability of the membrane for the intended applications, following tests were carried out and the results and discussions are presented as below.

\subsection{Solubility Test}

For proton exchange membrane, sufficient water content in the polymer electrolyte is desirable. Proton conductivity is directly proportional to the water content in the PEFMC which forms at the cathode. This water keeps the electrolyte at the correct level of hydration. The prime importance is that the membrane to be developed should be insoluble in water. Membranes of plain PVA membrane are soluble in water and hence their application in fuel cell gets nullified. Table 3 shows the solubility results of the membranes developed. Plain PVA membranes were soluble in water but membranes developed using PVA+MWCNT combinations were insoluble. Insolubility increased with increase in dosage of MWCNTs in the holding matrix. For increasing the weight of the MWCNTs dosage membranes will not dissolve and form nonhomogeneous mixture.

Table 3: Water Solubility Test

\begin{tabular}{|l|l|l|}
\hline \multicolumn{1}{|c|}{ Composition } & \multicolumn{1}{c|}{ Duration } & \multicolumn{1}{c|}{ Result } \\
\hline Plain PVA & $24 \mathrm{hrs}$. & Dissolved \\
\hline PVA+0.01g MWCNT & $24 \mathrm{hrs}$. & Not dissolved \\
\hline PVA+0.02g MWCNT & $24 \mathrm{hrs}$. & Not dissolved \\
\hline PVA+0.03g MWCNT & $24 \mathrm{hrs}$. & Not dissolved non homogeneous mixture \\
\hline PVA+0.04g MWCNT & $24 \mathrm{hrs}$. & Not dissolved non homogeneous mixture \\
\hline
\end{tabular}

Figures 6 (a), (b), (c) and (d) shows the results of the solubility test which was carried for time period of 24 hours.

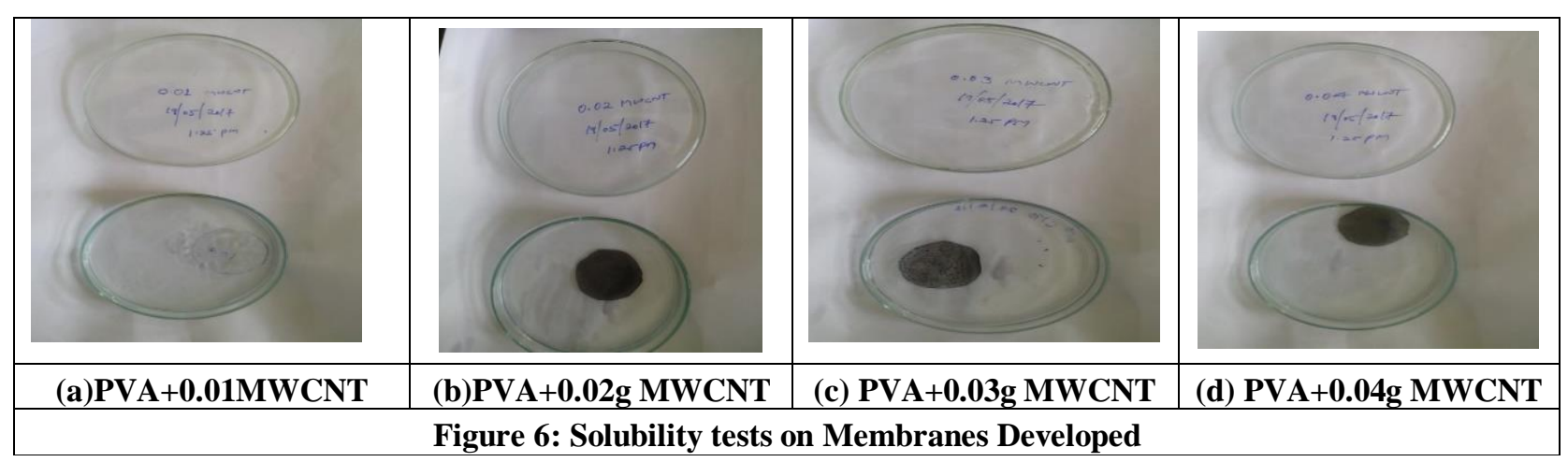

\subsection{Swelling Test}

Swelling test was carried out by submerging the developed membrane in various concentrations of Ethanol and water $(100 \%, 95 \%, 90 \%, 85 \%$, and $80 \%)$. The weight of the membranes is found out at the period of $24 \mathrm{hrs}, 48 \mathrm{hrs}, 72 \mathrm{hrs}$, respectively and average swollen rate is calculated on the basis of these readings, the degree of swelling is calculated by using following formula

$\%$ of Swelling $=(\mathrm{Ws}-\mathrm{Wd}) *(100) / \mathrm{Wd}$

Where Ws: Weight of Swollen Membrane

Wd: Weight of Dry membrane 
Fig. 7 shows the Swelling test carried out by submerging the membranes in various concentrations of Ethanol and Water. After test the obtained results are shown in different tables with various concentrations.

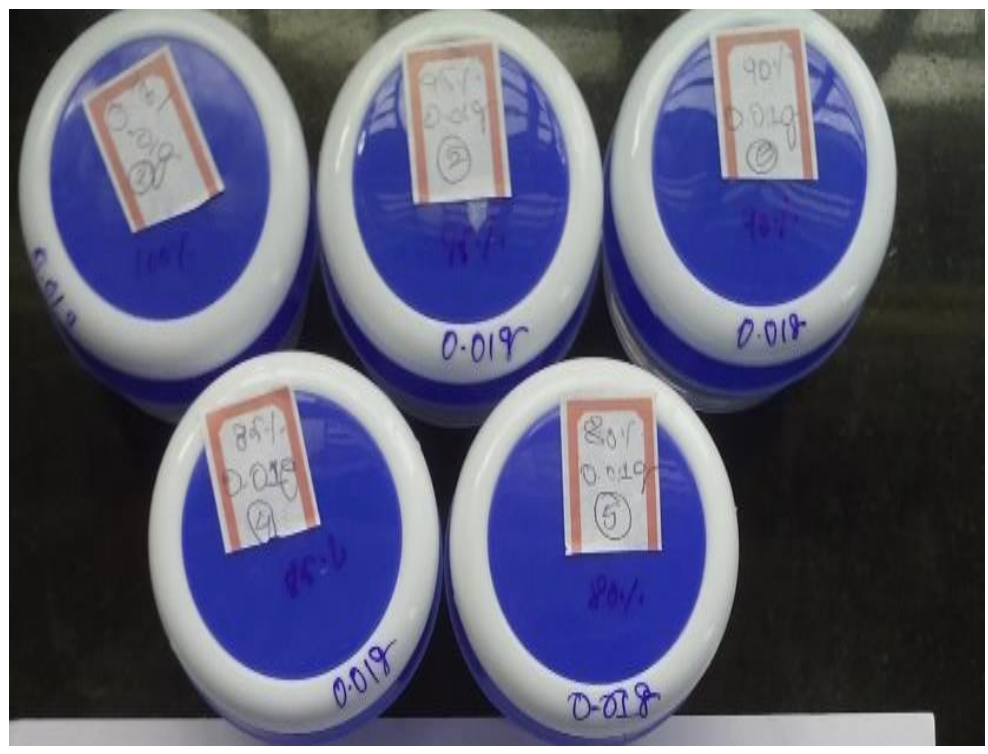

Figure 7: Swelling tests carried on membranes developed

\subsubsection{Plain PVA Membrane Tested results (M0)}

Tables 4 and 5 showtheresults of swelling test for only using PVA membrane and Ethanol. It has been found that while increasing the concentration of Ethanol the degree of degradation of the membrane decreases because of increased hydrophobic action.

Table 4: Swollen weight of Plain PVA Membrane

\begin{tabular}{|l|c|c|c|c|c|}
\hline \multicolumn{1}{|c|}{ Weight } & $\begin{array}{c}\mathbf{1 0 0 \%} \\
\text { Ethanol }\end{array}$ & $\begin{array}{c}\mathbf{9 5 \%} \text { Ethanol+ } \\
\mathbf{5 \%} \text { Water }\end{array}$ & $\begin{array}{c}\mathbf{9 0 \%} \text { Ethanol+ } \\
\mathbf{1 0 \%} \text { Water }\end{array}$ & $\begin{array}{c}\mathbf{8 5 \%} \text { Ethanol+ } \\
\mathbf{1 5 \%} \text { Water }\end{array}$ & $\begin{array}{c}\mathbf{8 0 \%} \text { Ethanol+ } \\
\mathbf{2 0 \%} \text { Water }\end{array}$ \\
\hline $\begin{array}{l}\text { Dry weight } \\
\text { (Wd) in grams }\end{array}$ & 0.0340 & 0.0412 & 0.0371 & 0.0381 & 0.0391 \\
\hline $\begin{array}{l}\text { Swollen Weight } \\
\text { (Ws) in grams }\end{array}$ & 0.0355 & 0.0425 & 0.0380 & 0.039 & 0.0403 \\
\hline
\end{tabular}

Table 5: Degree of Swelling in \% for Plain PVA Membrane

\begin{tabular}{|c|c|c|c|c|}
\hline $\mathbf{1 0 0 \%}$ Ethanol & $\begin{array}{c}\mathbf{9 5 \%} \text { Ethanol+ 5\% } \\
\text { Water }\end{array}$ & $\begin{array}{c}\mathbf{9 0 \%} \text { Ethanol+ 10\% } \\
\text { Water }\end{array}$ & $\begin{array}{c}\mathbf{8 5 \%} \text { Ethanol+ } \\
\mathbf{1 5 \%} \text { Water }\end{array}$ & $\begin{array}{c}\mathbf{8 0 \%} \text { Ethanol+ } \\
\mathbf{2 0 \%} \text { Water }\end{array}$ \\
\hline $4.22 \%$ & $3.05 \%$ & $2.36 \%$ & $2.55 \%$ & $2.97 \%$ \\
\hline
\end{tabular}

\subsubsection{PVA+0.01g of MWCNT Tested results (M1)}

Tables 6 and 7 shows that results of swelling test for PVA membrane mixed with 0.01g MWCNT nano particle, percentage of Ethanol and water. It has been found that while increasing the concentration of Ethanol with 0.01g MWCNT the degree of degradation of the membrane slowly decreased due to increased hydrophobic action.

Table 6: Swollen weights of Plain PVA Membrane+0.01g MWCNT

\begin{tabular}{|c|c|c|c|c|c|}
\hline Weight & $\mathbf{1 0 0 \%}$ Ethanol & $\begin{array}{c}\mathbf{9 5 \%} \text { Ethanol+ } \\
\mathbf{5} \% \text { Water }\end{array}$ & $\begin{array}{c}\mathbf{9 0 \%} \text { Ethanol+ } \\
\mathbf{1 0 \%} \text { Water }\end{array}$ & $\begin{array}{c}\mathbf{8 5 \%} \text { Ethanol+ } \\
\mathbf{1 5 \%} \text { Water }\end{array}$ & $\begin{array}{c}\mathbf{8 0 \%} \\
\text { Ethanol+ }\end{array}$ \\
\hline
\end{tabular}




\begin{tabular}{|l|c|c|c|c|c|}
\hline $\begin{array}{l}\text { Weight (Wd) in } \\
\text { grams }\end{array}$ & 0.0448 & 0.0406 & 0.0502 & 0.0440 & 20\% Water \\
\hline $\begin{array}{l}\text { Weight (Ws) in } \\
\text { grams }\end{array}$ & 0.0463 & 0.0418 & 0.0511 & 0.0448 & 0.0432 \\
\hline
\end{tabular}

Table 7: Degree of Swelling in \% for Plain PVA Membrane

\begin{tabular}{|c|c|c|c|c|}
\hline $\mathbf{1 0 0 \%}$ Ethanol & $\begin{array}{c}\mathbf{9 5 \%} \text { Ethanol+ 5\% } \\
\text { Water }\end{array}$ & $\begin{array}{c}\mathbf{9 0 \%} \text { Ethanol+ 10\% } \\
\text { Water }\end{array}$ & $\begin{array}{c}\mathbf{8 5 \%} \text { Ethanol+ } \\
\mathbf{1 5 \%} \text { Water }\end{array}$ & $\begin{array}{c}\mathbf{8 0 \%} \text { Ethanol+ } \\
\mathbf{2 0 \%} \text { Water }\end{array}$ \\
\hline $3.23 \%$ & $2.87 \%$ & $1.74 \%$ & $1.78 \%$ & $2.04 \%$ \\
\hline
\end{tabular}

\subsubsection{PVA+0.02g of MWCNT Tested Results (M2)}

Tables 8 and 9 shows that results of swelling test for PVA membrane mixed with 0.02g MWCNT nano particle, percentage of Ethanol and water. It has been found that while increasing the concentration of Ethanol with 0.02g MWCNT the degree of degradation of the membrane decreased due to increased hydrophobic action.

Table 8: Swollen weights of Plain PVA Membrane+0.02g MWCNT

\begin{tabular}{|l|c|c|c|c|c|}
\hline \multicolumn{1}{|c|}{ Weight } & $\begin{array}{c}\mathbf{1 0 0 \%} \\
\text { Ethanol }\end{array}$ & $\begin{array}{c}\mathbf{9 5 \%} \text { Ethanol+ } \\
\mathbf{5 \%} \text { Water }\end{array}$ & $\begin{array}{c}\mathbf{9 0 \%} \text { Ethanol+ } \\
\mathbf{1 0 \%} \text { Water }\end{array}$ & $\begin{array}{c}\mathbf{8 5 \%} \text { Ethanol+ } \\
\mathbf{1 5 \%} \text { Water }\end{array}$ & $\begin{array}{c}\mathbf{8 0 \%} \text { Ethanol+ } \\
\mathbf{2 0 \%} \text { Water }\end{array}$ \\
\hline $\begin{array}{l}\text { Weight (Wd) in } \\
\text { grams }\end{array}$ & 0.0508 & 0.0480 & 0.0431 & 0.0502 & 0.0575 \\
\hline $\begin{array}{l}\text { Weight (Ws) in } \\
\text { grams }\end{array}$ & 0.0522 & 0.0490 & 0.0438 & 0.0509 & 0.0585 \\
\hline
\end{tabular}

Table 9: Degree of Swelling in \% for Plain PVA Membrane+0.02g MWCNT

\begin{tabular}{|c|c|c|c|c|}
\hline $\mathbf{1 0 0 \%}$ Ethanol & $\begin{array}{c}\mathbf{9 5 \%} \text { Ethanol+ 5\% } \\
\text { Water }\end{array}$ & $\begin{array}{c}\mathbf{9 0 \%} \text { Ethanol+ } \\
\mathbf{1 0 \%} \text { Water }\end{array}$ & $\begin{array}{c}\mathbf{8 5 \%} \text { Ethanol+ 15\% } \\
\text { Water }\end{array}$ & $\begin{array}{c}\mathbf{8 0 \%} \text { Ethanol+ } \\
\mathbf{2 0 \%} \text { Water }\end{array}$ \\
\hline $2.68 \%$ & $2.04 \%$ & $1.59 \%$ & $1.37 \%$ & $1.70 \%$ \\
\hline
\end{tabular}

\subsubsection{PVA+0.03g of MWCNT Tested Results (M3)}

Tables 10 and 11 shows that results of swelling test for PVA membrane mixed with 0.03g MWCNT nano particle, percentage of Ethanol and water. It has been found that while increasing the concentration of Ethanol with $0.03 \mathrm{~g}$ MWCNT the degree of degradation of the membrane decreased due to increased hydrophobic action.

Table 10: Swollen Weights of Plain PVA Membrane+0.03g MWCNT

\begin{tabular}{|c|c|c|c|c|c|}
\hline Weight & $\begin{array}{c}\mathbf{1 0 0 \%} \\
\text { Ethanol }\end{array}$ & $\begin{array}{c}\mathbf{9 5 \%} \text { Ethanol+ } \\
\mathbf{5 \%} \text { Water }\end{array}$ & $\begin{array}{c}\mathbf{9 0 \%} \text { Ethanol+ } \\
\mathbf{1 0 \%} \text { Water }\end{array}$ & $\begin{array}{c}\mathbf{8 5 \%} \text { Ethanol+ } \\
\mathbf{1 5 \%} \text { Water }\end{array}$ & $\begin{array}{c}\text { 80\% Ethanol+ } \\
\mathbf{2 0 \%} \text { Water }\end{array}$ \\
\hline $\begin{array}{c}\text { Weight } \\
\text { (Wd) in } \\
\text { grams }\end{array}$ & 0.0438 & 0.0422 & 0.0432 & 0.0440 & 0.0466 \\
\hline $\begin{array}{c}\text { Weight } \\
\text { (Ws) in } \\
\text { grams }\end{array}$ & 0.0450 & 0.0427 & 0.0436 & 0.0446 & 0.0471 \\
\hline
\end{tabular}

Table 11: Degree of Swelling in \% for Plain PVA Membrane+0.03g MWCNT

\begin{tabular}{|c|c|c|c|c|}
\hline $\mathbf{1 0 0 \%}$ Ethanol & $\begin{array}{c}\text { 95\% Ethanol+ 5\% } \\
\text { Water }\end{array}$ & $\begin{array}{c}\text { 90\% Ethanol+ 10\% } \\
\text { Water }\end{array}$ & $\begin{array}{c}\mathbf{8 5 \%} \text { Ethanol+ } \\
\mathbf{1 5 \%} \text { Water }\end{array}$ & $\begin{array}{c}\mathbf{8 0} \% \text { Ethanol+ } \\
\mathbf{2 0 \%} \text { Water }\end{array}$ \\
\hline
\end{tabular}




\begin{tabular}{|l|l|l|l|l|}
\hline $2.66 \%$ & $1.17 \%$ & $0.91 \%$ & $1.34 \%$ & $1.06 \%$ \\
\hline
\end{tabular}

\subsubsection{PVA+0.04g of MWCNT Tested results (M4)}

Tables 12 and 13 shows that results of swelling test for PVA membrane mixed with 0.04g MWCNT nano particle, percentage of Ethanol and water. It has been found that while increasing the concentration of Ethanol with 0.04g MWCNT the degree of degradation of the membrane decreased because of increased hydrophobic action.

Table 12: Swollen weights of Plain PVA Membrane+0.04g MWCNT

\begin{tabular}{|c|c|c|c|c|c|}
\hline Weight & $\begin{array}{c}\mathbf{1 0 0 \%} \\
\text { Ethanol }\end{array}$ & $\begin{array}{c}\mathbf{9 5 \%} \text { Ethanol+ } \\
\mathbf{5 \%} \text { Water }\end{array}$ & $\begin{array}{c}\mathbf{9 0 \%} \text { Ethanol+ 10\% } \\
\text { Water }\end{array}$ & $\begin{array}{c}\mathbf{8 5 \%} \text { Ethanol+ } \\
\mathbf{1 5 \%} \text { Water }\end{array}$ & $\begin{array}{c}\mathbf{8 0 \%} \text { Ethanol+ } \\
\mathbf{2 0 \%} \text { Water }\end{array}$ \\
\hline $\begin{array}{c}\text { Weight (Wd) } \\
\text { in grams }\end{array}$ & 0.0369 & 0.0399 & 0.0418 & 0.0373 & 0.0366 \\
\hline $\begin{array}{c}\text { Weight (Ws) } \\
\text { in grams }\end{array}$ & 0.0377 & 0.0403 & 0.0419 & 0.0378 & 0.0368 \\
\hline
\end{tabular}

Table 13: Degree of Swelling in \% for Plain PVA Membrane+0.04g MWCNT

\begin{tabular}{|c|c|c|c|c|}
\hline $\begin{array}{c}\mathbf{1 0 0 \%} \\
\text { Ethanol }\end{array}$ & $\begin{array}{c}\mathbf{9 5 \%} \text { Ethanol+ 5\% } \\
\text { Water }\end{array}$ & $\begin{array}{c}\mathbf{9 0 \%} \text { Ethanol+ 10\% } \\
\text { Water }\end{array}$ & $\begin{array}{c}\mathbf{8 5 \%} \text { Ethanol+ 15\% } \\
\text { Water }\end{array}$ & $\begin{array}{c}\mathbf{8 0 \%} \text { Ethanol+ 20\% } \\
\text { Water }\end{array}$ \\
\hline $2.12 \%$ & $0.992 \%$ & $0.238 \%$ & $1.32 \%$ & $0.54 \%$ \\
\hline
\end{tabular}

Fig 8 and 9 shows after swelling test carried out by submerging the membranes in various concentration of Ethanol and Water and PVA concentration and from figures it is clear that after swelling test for the submerging the membranes in various concentration of ethanol, water and PVA concentration the weight of the plain membrane and swelled membranes.

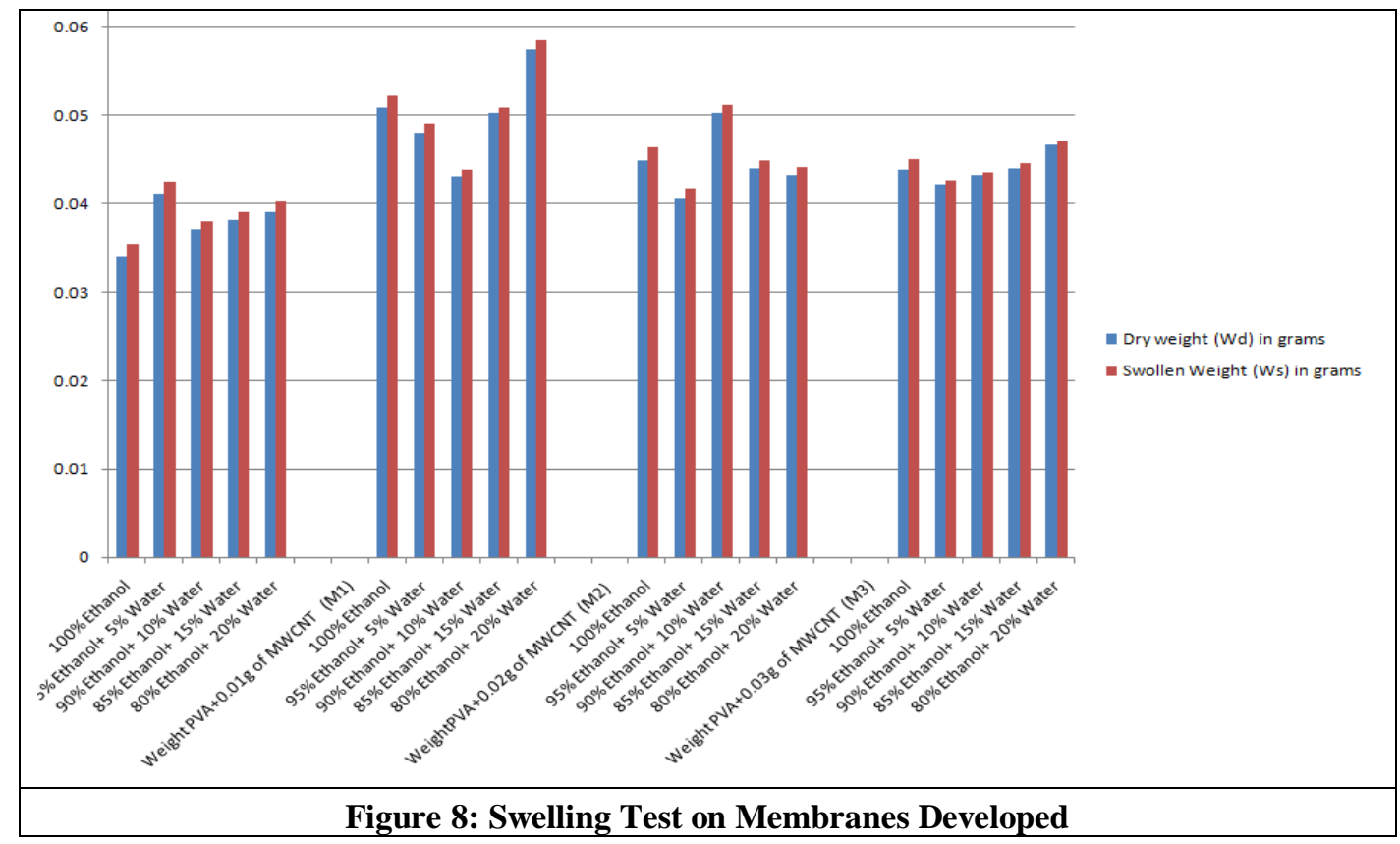

\subsection{Fourier Transform Infrared Spectroscopy Analysis (FTIR)}

Analysis of the position, shape and intensity of peaks in the FTIR spectrum reveals the details about molecular structure of 
the samples tested. Membrane samples were converted to powder form before the testing. FTIR spectra of PVA added MWCNTs were tested using a FT-IR spectrometer (Perkin-Elmer, model spectrum one. FTIR spectra were obtained in a range of frequency from $4000 \mathrm{~cm}^{-1}$ to $450 \mathrm{~cm}^{-1}$ with a resolution of $4 \mathrm{~cm}^{-1}$. The Peak around $3440 \mathrm{~cm}^{-1}$ corresponds to hydroxy group (OH) which presents in MWCNTs samples (1). Peak at $1741 \mathrm{~cm}^{-1}$ corresponds toC $=\mathrm{O}$ bands (2) and 1630 $\mathrm{cm}^{-1}$ corresponds toC $=\mathrm{C}$ Stretching bands (3). The range of vibrations range from 1333 to 1487 corresponds to $\mathrm{CH}_{2}$ bending (1). Lower peaks at 1132 correspond to both C-O-C and C-C band. At lowest of 1040 due to the C-OH stretching Vibrations (3). The FTIR measurements have validated the attachments of strongly hydrogen-bonded hydroxyl moieties $(\mathrm{O}-\mathrm{H})$ and carbonyl group $(\mathrm{C}=\mathrm{O})$ to MWCNTs.

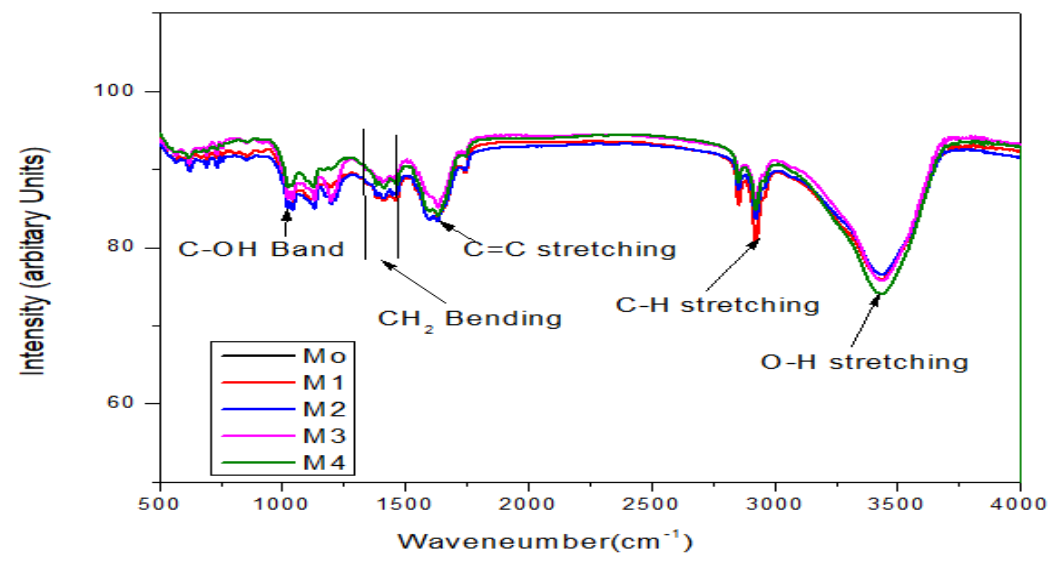

Figure 11: FTIR Spectra of Membranes with MWCNTs

\subsection{Thermo Gravimetric Analysis (TGA Tests)}

TGA provides information about chemical phenomena such as second order phase transition,includingvaporization, sublimation,absorption,adsorption,desorption it can also provide information about physical phenomena such as dehydration, chemisorption and decomposition. The developed samples were investigated for TGA with a rate of heat $10^{\circ} \mathrm{C} / \mathrm{min}$ up to $600^{\circ} \mathrm{C}$. The TGA of the Plain PVA polymer shows that there is the thermal stability of the PVA film up to $40^{\circ} \mathrm{C}$. From ambient to $600^{\circ} \mathrm{C}$ of temperature; there were three apparent weight loss steps.

Prior to $102^{\circ} \mathrm{C}$, a weight drop of $7 \%$ was due to the evaporation of surface and structural water. Since the film pattern was dried at $33^{\circ} \mathrm{C}$, there was a little water in the template.

- The large weight loss of $71 \%$ between 275 and $339^{\circ} \mathrm{C}$ is attributed to the decomposition and combustion of the PVA film template.

- In the temperature range of 461 to $593^{\circ} \mathrm{C}$ a weight loss of $10 \%$ was due to the transformation from carbon black to carbon dioxide, as temperature was increased beyond $600^{\circ} \mathrm{C}$ no mass loss might be noted.

On comparing above graph with plain PVA it was inferred that, membrane containing 0.01g of MWCNT showed better thermal degradation property. In temperature range of 478 to $587^{\circ} \mathrm{C}$ the weight loss vary from $25 \%$ but remains constant $19 \%$ in range of 587 to $600^{\circ} \mathrm{C}$.

On comparing above graph with plain PVA it was inferred that, membrane containing 0.02g of MWCNT showed better thermal degradation property, But on comparing with M1 it seems that there is slight decrease in weight loss. In 
temperature range of 478 to $560^{\circ} \mathrm{C}$, the weight loss varies from $21 \%$ but remains constant at $15 \%$ in range of 560 to $600^{\circ} \mathrm{C}$. On comparing above graph with plain PVA it was inferred that, membrane containing 0.03g of MWCNT showed better thermal degradation property, and when compare to M1 and M2 respectively the thermal degradation property of M3 increases. In temperature range of 478 to $581^{\circ} \mathrm{C}$ the weight loss varies from $26.48 \%$ but remains constant $21 \%$ in range of 587 to $600^{\circ} \mathrm{C}$.On comparing above graph with plain PVA it was inferred that, membrane containing 0.04g of MWCNT showed better thermal degradation property. And it showed very good thermal degradation property than the M1, M2, and $\mathrm{M} 3$ respectively. In temperature range of 478 to $554^{\circ} \mathrm{C}$ the weight loss vary from $33 \%$ but remains constant $28 \%$ in range of 554 to $600^{\circ} \mathrm{C}$.

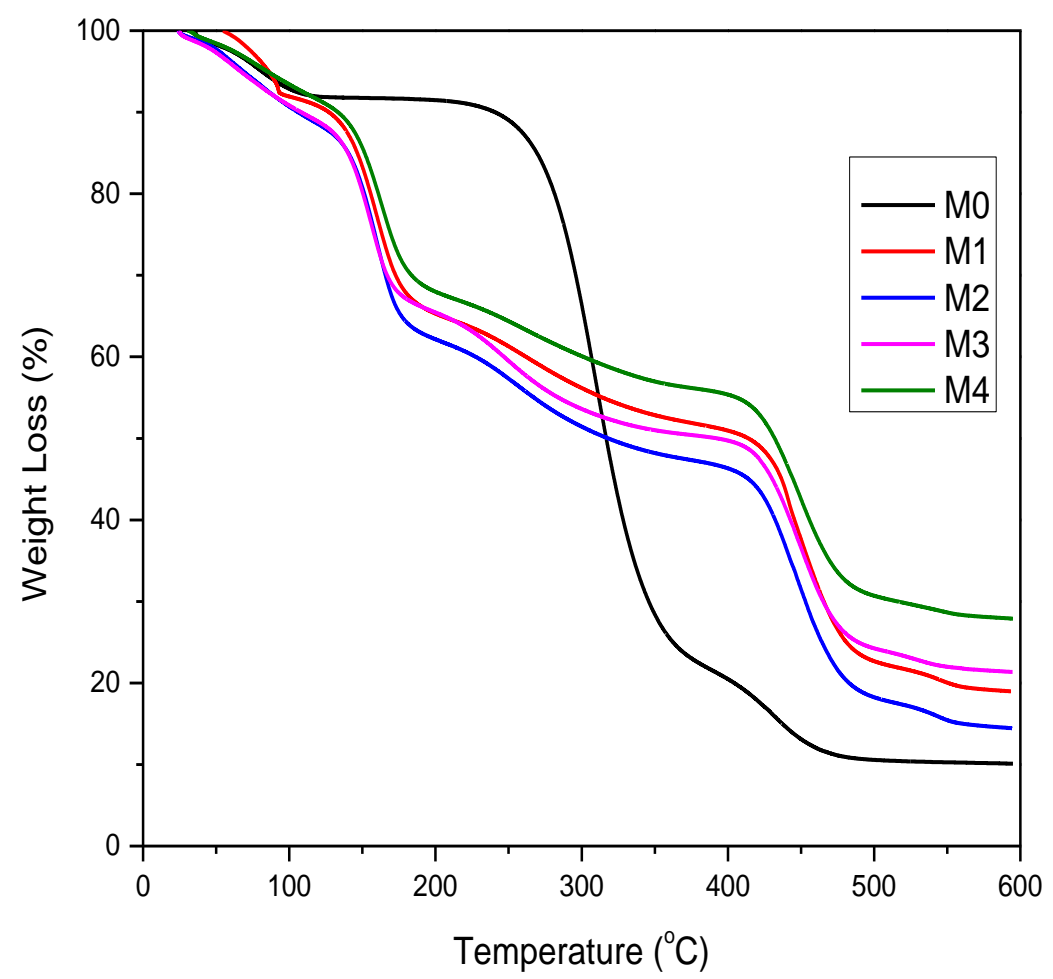

Figure 13: Thermo Gravimetric Analysis of MWCNTs based Membranes

\subsection{Scanning Electronic Microscope (SEM) Analysis}

Figure14 shows the plain PVA and it has smooth surface. When MWCNTs added to the PVA, the surface contains cracks and their length increased for 0.02g MWCNTs than 0.01g. This crack formed while taking out sample from the glass plate. We could observe busted air bubbles in sample 0.03g which formed during solution pouring on glass slide and setting process. And 0.04 shows the uneven surface, accumulated MWCNTs randomly in the PVA and caused by the non-uniform dispersion of MWCNTs in the PVA. Fig 14 to 18 shows the SEM analysis of the PVA and MWCNT with varying composition. 


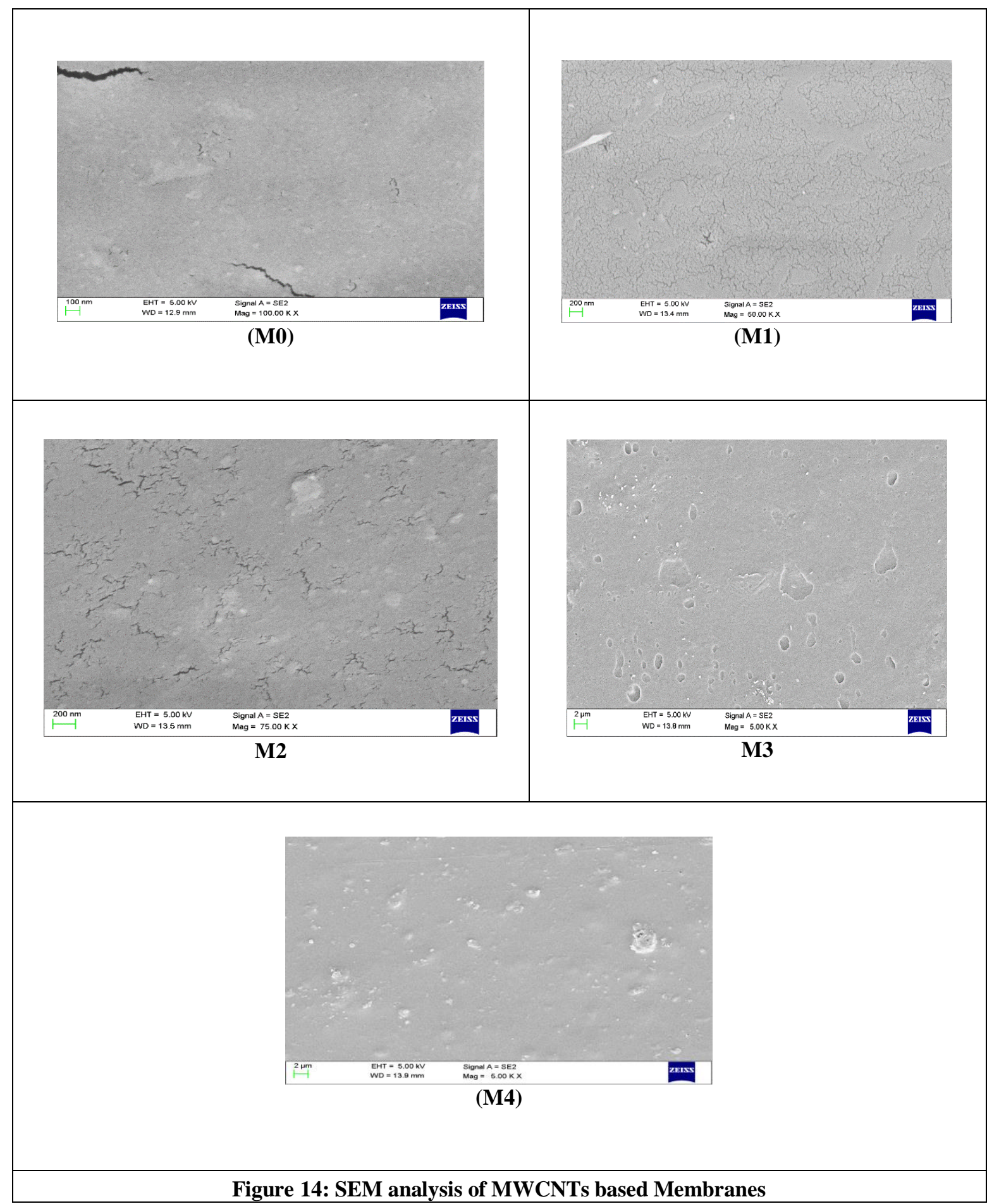

\section{CONCLUSIONS}

Membrane were developed using various combination of MWCNTs in the PVA holding matrix and it from the study it was found that PVA+0.04g of MWCNT showed a suitable membrane for fuel cell applications. The following conclusions were made from the study:

- From TGA Analysis it was found that increasing the concentration of MWCNT thermal stability increased and PVA+0.04g MWCNT (M4) showed higher thermal stability. 
- FTIR Spectroscopy analysis confirmed attachment of MWCNT on PVA surfaces which increased with increase in concentration of MWCNT in PVA Membrane.

- Solubility test showed solubility of membranes in water decreased with the combination of PVA+MWCNT.

- Swelling test showed increasing the concentration of MWCNT the degree of degradation of the membrane decreased because of increased hydrophobic action. Accordingly, PVA+0.04g(M4) MWCNT membrane showed lower degree of membrane degradation.

\section{ACKNOWLEDGEMENTS}

Authors are grateful to all the institutes for providing support and assistance in this research work.

\section{REFERENCES}

1. Pathy, Kumar Chittarajan.D.R. (Ed). 2007. Forest, Government, and the Tribe. New Delhi: Concept of Publishing Company.

2. ALIZADEH, ASAD, and ANAS ABID MATTIE. "TWO-DIMENSIONAL SIMULATION TO INVESTIGATE THE INTERACTION OF FLUID-STRUCTURE INSIDE A MICROCHANNEL WITH ELASTIC AND RIGID BOUNDARY." International Journal of Mechanical and Production Engineering Research and Development (IJMPERD) 9.4, Aug 2019, $1151-1156$

3. Alrwashdeh, SAAD S. "An Energy Production Evaluation from PV Arrays with Different Inter-Row Distances." International Journal of Mechanical and Production Engineering Research and Development (2019): 9-5.

4. Alghunaim N.S., 2016. "Optimization and spectroscopic studies on carbon nanotubes/PVA nanocomposites", Results in Physics, 6 (2016) 456-460.

5. Bae, B., Chun, B-H, Ha, H-Y, Oh I-H, Kim, D. 2002. "Preparation and characterization of plasma treated PP composite electrolyte membrane. Journal of Membrane Science 202: 245-52.

6. Basarir, F., Choi E.Y, Moon, S.H, Song, K.C, Yoon, TH. 2006. "Electrochemical properties of Poly propylene membranes modified by the plasma polymerization coating of SO2/acetylene." J Applied Polymer Science 99: 3692-99.

7. Beydaghi, H., M. Javanbakht, and A. Badiei. 2014. "Cross-linked PVA/sulfonated nano porous silica hybrid membranes for proton exchange membrane fuel cell." Journal of Nano structural Chemistry 97 - 1-9.

8. Chen, J., J. Wu, C. Lee, M. Tsai, and K. Chen. 2015. "Novel polyimides containing benzimidazole for temperature proton exchange membrane fuel." Journal of Membrane Science 483: 144-154.

9. Chen, J., Asano, M., Maekawa, Y., Sakamura T., Kubota H., and Yoshida M. 2006. "Preparation of ETFE based fuel cell membranes using UV-induced photo grafting and electron beam-induced cross-linking techniques." Journal of Membrane Science 283: 373-379.

10. Feng, S., K. Shen, Y., Wang, J. Pang, and Z. Jiang. 2013. "Concentrated sulfonated poly (ether sulfone) as proton exchange membranes. " Journal of Power Sources 224: 42-49.

11. Hickner, M.A., H. Ghassemi, Y.S. Kim, B.R. Einsla, and J.E. Mc Grath. 2004. "Alternative Polymer Systems for Proton Exchange Membranes (PEMs)." Chem. Rev. ACS Publications 104: 4587-4612.

12. Hietala, S., Holmberg, S., Karjalainen S M., Nasman, J., Paronen M., Serimaa, R., Sundholm, F., and Vahvaselka, S. 1995. "Structural investigation of radiation grafted and sulfonated poly (vinyl idene fluoride)." PVDF membranes Journal of Material Chemistry 5: 721-26. 
13. Jeong, Y., J. Jung, E. Choi, S. Han, A.I. Begley, S.J. Yoo, J.H. Jang, H. Kim, S.W. Nam, K. Lee, and J.Y. Kim. 2015. "Colorimetric determination of phosphoric acid leakage for hosphoric acid-doped poly benzimidazole membrane fuel cell applications. ” Journal of Power Sources 299: 480-484.

14. JINDAL, HIMANSHU, AMANDEEP SINGH OBEROI, and INDERJEET SINGH SANDHU. "A REDUCED GRAPHENE OXIDE ELECTRODE FOR SOLID-STATE HYDROGEN STORAGE WITHIN A PROTON BATTERY." International Journal of Mechanical and Production Engineering Research and Development IJMPERD) 9.4, Aug 2019, 659-670

15. Kim, Y. S., Wang, F., Hickner, M., Zawodzinski, T. A., and McGrath, J. E. 2003. "Fabrication and characterization of heteropoly acid (H3PW12O40)/directly polymerized sulfonated poly (arylene ether sulfone) copolymer composite membranes for higher temperature fuel cell applications. ”Journal of Membrane Science 212: 263-82.

16. Kerres, J., Ullrich, A., Meier, F., and Haring, T. 1999. "Synthesis and characterization of novel acid-base polymer blends for application in membrane fuel cells.” Journal of Solid-State Ionics 125: 243-49.

17. Ko, T., K. Kim, M. Lim, S.Y. Nam, T. Kim, S. Kim, and J. Lee. 2015. "Sulfonated poly (arylene ether sulfone) composite membranes having poly(2,5-benzimidazole)-grafted graphene oxide for fuel cell applications. " Journal of Material Chemistry, 3: 20595-20606.

18. Kumar, G.G., Kim, A.R., Nahm, K.S., Yoo, D.J., and Elizabeth, R. 2010. "High ion and lower molecular transportation of the poly vinylidene fluoride-hexafluoro propylene hybrid membranes for the high temperature and lower humidity direct methanol fuel cell applications. "Journal of Power Sources 195: 5922-28.

19. Lee, C.H., Xie W., Van, Houthe, D., McGrath, J.E., Freeman, B.D., Spano, J., Wi, S., Park, C.H., and Lee, Y.M. 2012. "Hydrophilic silica additives for difulfonated poly (arylene ether sulfone) random copolymer membranes." Journal of Membrane Science392-393.

20. Leticia, García-Cruz, Clara, Casado-Coterillo, Ángel Irabien, Vicente Montiel, and Jesus Iniesta. 2016. "High Performance of Alkaline Anion-Exchange Membranes Based on Chitosan/Poly (vinyl) Alcohol Doped with Graphene Oxide for the Electro oxidation of Primary Alcohols. ” Journal of Carbon research, DOI:10.3390/c2020010.

21. Liang, G.Z., Lu, T.L., Ma, X.Y., Yan, H.X., and Gong, Z.H. 2003. "Synthesis and characteristics of radiation-grafted membranes for fuel cell electrolytes." Polymer International 52: 1300-08. https://doi.org/10.1002/pi.1220.

22. Li, W., Manthiram, A., and Guiver, M.D. 2010. "Acid-base blend membranes consisting of sulfonated poly (etherether ketone) and 5-amino-benzotriazole tethered polysulfone for DMFC.” Journal of Membrane Science, 362:289-97.

23. Li, L., Wang, S., Hui, D., and Qiu, J. 2015. "Ordered multiphase polymer nano composites for high-performance solid-state super capacitors." Composites: part B 71: 40-44.

24. Lu, H., Yin J., Xu, B., Gou J., Hui, D., and Fu, Y. 2016. "Synergistic effects of carboxylic acid-functionalized carbon nano tube and nafion/silica nano fiber on electrical actuation efficiency of shape memory polymer nano composite.” Composites: part B 100:146-151

25. Maekawa, Chen, J.Y., Asano, M., and Yoshida, M. 2007. "Double cross linked polyether ether ketone-based polymer electrolyte membranes prepared by radiation and thermal cross linking techniques.” Journal of Polymer 48: 6002-09.

26. Min Juey, Yee, 2018. "Synthesis of polyvinyl alcohol (PVA) infiltrated MWCNTs buckypaper for strain sensing application, scientific reports”. Scientific Reports, volume 8, Article number: 17295 (DOI:10.1038/s41598-018-35638-3.

27. Miyatake, K., H. Furuya, M. Tanaka, and M. Watanabe. 2012. "Durability of sulfonated polyimide membrane in humidity cycling for fuel cell applications.” Journal of Power Sources 204: 74-78. 
28. Munavalli, B., A. Torvi, and M. Kariduraganavar. 2018. "A facile route for the preparation of proton exchange membranes using sulfonated side chain graphite oxides and cross-linked sodium alginate for fuel cell." Polymer 142-293e30

29. Park, K.R., Kang, P.H., Nho, Y.C. 2005. "Preparation of PFA-g-polystyrene sulfonic acid membranes by the radiation grafting of styrene onto PFA films." Reactive and Functional Polymer 65: 47-56.

30. Phu, D.S., Lee, C.H., Park, C.H., Lee, S.Y., and Lee, Y.M., 2009. "Synthesis of cross linked sulfonated poly (phenylene sulfide sulfone nitrile) for direct methanol fuel cell applications. " Macromol Rapid communication 30: 64-68.

31. Schönberger, F., Hein M., and Kerres, J. 2007. "Preparation and characterization of sulfonated partially fluorinated statistical poly (arylene ether sulfone)s and their blends with PBI. ” Journal of Solid State Ionics 178: 547-54.

32. Tamilselvan, T., and S. C. Prasanna. "Review on the Effect of Nanofiller Addition on the Technical Properties of Polymers." International Journal of Mechanical and Production Engineering Research and Development (IJMPERD) ISSN (P) (2018): 2249-6890.

33. Vinayan B. P., 2012. "Synthesis of graphene-multiwalled carbon nanotubes hybrid nanostructure by strengthened electrostatic interaction and its lithium ion battery application” Journal of Materials Chemistry, 2012, 22, 9949-9956.

34. Won, J., Choi, S.W., Kang, Y.S., Ha, H.Y., Oh I.H., Kim, H.S., Kim, K.T., and Jo, W.H. 2003. “Structural characterization and surface modification of sulfonated polystyrene-(ethylene-butylene)-styrene triblock proton exchange membranes." Journal of Membrane Science 214: 245-57.

35. Yang, S., Y. Ahn, and D. Kim. 2017. "Poly (arylene ether ketone) proton exchange membranes grafted with long aliphatic pendant sulfonated groups for vanadium redox flow batteries. ” Journal of Material Chemistry A 5 - 2261-2270.

36. Zhu, M., Song, Y., Hu W., Li X., Jiang, Z., Guiver, M.D., and Liu B. 2012. "A peak-based binary blends and ternary composites as proton exchange membranes for DMFC." Journal of Membrane Science 520-526.

37. Zhao C., H. Lin, and H. Na. 2010. "Novel cross-linked sulfonated poly (arylene ether ketone) membranes for direct methanol fuel cell." International Journal of Hydrogen Energy 35: 2176-2182. 
